\title{
FUNDAMENTALISMS AND PATRIARCHAL GENDER POLITICS
}

\author{
Martin Riesebrodt and Kelly H. Chong
}

\begin{abstract}
Recent studies of North American and Latin American evangelicalism suggest that the ideology and politics of charismatic and legalistic-literalist fundamentalist groups differ with regard to gender relations. Although both advocate patriarchal structures of authority, women in charismatic groups can negotiate gender relations more actively, thereby promoting their own interests. Applying this basic distinction to evangelical groups in South Korea, however, suggests that differences among the outcomes for women depend on preexisting structures of authority rather than the type of fundamentalism. When patriarchal structures of authority, especially in the family, still function, the differences between charismatic and legalistic-literalist fundamentalism become minimized. However, when these structures are breaking down or already have eroded, charismatic types of fundamentalism offer women a stronger voice and greater opportunities to renegotiate gender relations than do literalist-legalistic ones.
\end{abstract}

$\mathrm{M}$ uch attention has been paid over the last two decades to the dramatic global resurgence of highly politicized religious movements. Given the traditional expectations of secularization, these events have surprised many and numerous conferences and publications have been organized recently in an effort to understand these phenomena. ${ }^{1}$ Based on the differentiation and rationalization of modern and modernizing societies, religion was supposed to be replaced in part by science, or limited in its significance to the private sphere. Others expected religious values to become the foundation of a general morality beyond any denominationalism. ${ }^{2}$ But very few anticipated the reemergence of attempts by religious groups to gain political power or even conquer the state in order to implement a social order supposedly based on eternal, timeless principles prescribed by their religion-what Nikki R. Keddie labels "new religious politics" and others call "fundamentalism." ${ }^{3}$ What has been even more puzzling is the active participation of women in religious movements that advocate a return to or strict enforcement of patriarchal structures of authority and morality. 
Much of the surprise regarding the resurgence of religion and the participation of women in fundamentalist movements has been due, on the one hand, to a conventional and broadly functionalist understanding of religion, and, on the other hand, a somewhat abstract and socially noncontextualized image of patriarchalism. Both are based on ethnocentric notions of modernization, progress, and history. ${ }^{4}$ In order to better understand both events (which we regard as interrelated), theorists need to revise the concepts of religion and secularization as well as abstract Western emancipatory models which were developed under very specific social, political, and historic circumstances. Women's active participation in recent fundamentalist religious movements urges us to realistically identify their interests under given political, cultural, social, and economic circumstances and constraints, a task several authors recently have undertaken.

Most attention has been paid to politicized Islamic movements, a focus that has contributed to stigmatization of Islam or to the false impression that new religious politics is a predominantly Muslim phenomenon. To correct these notions we focus on similar Protestant movements in Latin America, North America, and South Korea. Moreover, this article emphasizes that new religious politics covers only certain types of religiously legitimated patriarchal gender politics.

The growing literature on Pentecostalism and evangelicalism, especially in Latin America, is of great significance to the understanding of women's participation in patriarchally oriented religious movements, offering valuable insights into the social, economic, and cultural contexts of religious gender politics. Although most Pentecostal and evangelical groups reject direct involvement in politics and do not want to pressure or conquer the state, scholars have characterized them as attempts of largely lower-class women to restructure and remoralize the patriarchal family against the destructive forces of machismo. ${ }^{5}$ A comparison of seemingly apolitical movements and supposedly more political fundamentalisms may help us to better understand the involvement of women in both kinds of religious groups. Moreover, although apolitical at present, the domestic gender politics of charismatic grassroots movements may become politicized under certain circumstances and may have great political effects over time.

In this article, we first address the issues of secularization and the global resurgence of religion, and offer a definition and typology of fundamentalism. Second, we turn to two types of patriarchally oriented religious groups: politically active legalistic-literalist fundamentalism and less obviously political charismatic fundamentalism. The literature on North American and Latin American fundamentalism suggests that charismatic 
movements tend to represent a self-organization of women actively attempting to reshape the patriarchal family in their own interest, whereas legalistic-literalist fundamentalism tends to represent the selforganization of men who compensate for loss of authority and status by increasing their control over women. Although this opposition may have some merit in North American and Latin American contexts, it is exaggerated and does not account for the motivation either of men joining charismatic groups or women joining legalistic-literalist groups. Furthermore, a comparison to the South Korean case suggests that men can dominate equally charismatic fundamentalism and legalistic-literalist fundamentalism. We conclude that different outcomes depend less on the type of fundamentalism than on existing authority structures. When patriarchal structures of authority, though threatened, still function in the family, workplace, and gender relations, literalist-legalistic as well as charismatic types of fundamentalism tend to affirm and stabilize male authority. When patriarchal structures of authority either break down and are transformed into nonpatriarchal partnerships or degenerate into machismo, gender relations can be renegotiated. When this is the case, one can observe two major differences between charismatic and literalist-legalistic groups. Although both types of fundamentalism advocate strict patriarchal authority and morality, charismatic fundamentalism offers women a stronger voice and greater opportunities in the renegotiation of gender relations than literalist-legalistic fundamentalism. Moreover, this process tends to take different forms. Literalist-legalistic fundamentalism often organizes itself in terms of new religious politics, whereas charismatic fundamentalism focuses more narrowly on domestic relations.

\section{Secularization and the Global Resurgence of Religion}

Secularization has been defined in different ways: as institutional differentiation, where religious and state institutions are separated by law; as a decline in the plausibility of religions to provide structures of meaning due to the progress in scientific explanations; and as the reduction of religious significance to the private sphere. No matter how one understands secularization, the recent resurgence of religious movements renders these ideas highly problematic, since they are based on a rationalist and functionalist understanding of religion. Confronted with the global resurgence of religious movements, most conventional theories deny empirical evidence one way or another, either claiming that secularization never really took place, or that the reemergence of religious movements over the last decades is actually part of the secularization process. It seems 
obvious to us that both secularization and the return to religion not only have taken place but are interrelated.

In order to better understand and explain both processes, we shift the emphasis from a theological or philosophical focus to a more pragmatic perspective which analyzes religions in terms of cultural systems of crisis prevention and management. ${ }^{6}$ Religious practices are based on two core assumptions: First, there exist superhuman powers or extraordinary forces which control dimensions of life beyond direct human control; second, religious actors gain access to these powers through culturally specific means. Religious practices are thus culturally patterned attempts to access "higher powers" in order to prevent crises or cope with them when they have occurred. ${ }^{7}$

Religious practices are, of course, interlinked with and shaped by the social and institutional order of any given society. How a society defines and frames crises and which coping strategies and modes of mediation it regards as appropriate, who controls the legitimate means of religious mediation-all these are socially regulated and objects of institutionalization and division of labor. In these respects, religious systems function much like political systems of authority; they offer complex repertoires of beliefs and practices which can be instrumentalized selectively not only for the legitimation of authority and privilege, but also for their delegitimation and transformation. And religion, in turn, can contribute to the shaping of the social, economic, and political order.

Seen from this theoretical perspective, secularization has taken place as a consequence of increasing human control and "world-mastery." Most important, massive expansion of scientific knowledge, advances in medicine, and expansion of the welfare state have immensely reduced the risks and threats and, consequently, the relevance of religion. However, in part simultaneously and in part consequently, new dimensions of uncertainty, risk, and powerlessness have opened up. Science and technology have not only extended our control of nature, but also have created such new risks as environmental catastrophes or the threat of atomic war. Democratization not only has profaned politics but has opened up opportunities for charismatic leaders to mobilize mass support, often in reaction to the failures or problematic effects of Western liberalism or socialism. Capitalism as a revolutionary force has made labor a commodity, exposed people to market uncertainties, destabilized existing family structures, and increased social and spatial mobility. Accordingly, these instabilities have been the source of the formation of new religious groups and movements. Seen from this perspective, religion appears as an arena where different groups and categories of people address specific risks and attempt to re- 
negotiate social relations, structures of authority, and morality in the name of higher powers.

Religious movements are particularly interesting, since they are responses of definite social groups to perceived social crises. Most important, moments of crisis lead to a redefinition of what adherents to these movements believe their higher powers want them to do to restore the natural, bodily, social, or cosmic order. Since the knowledge of the will of these powers is only accessible through certain procedures, competition exists among different individuals, groups, and categories of people claiming authoritative knowledge of the ideal social, moral, and political order that the religion demands.

In general, there are two major religious reactions to the crises of modernity: utopian and mythical. ${ }^{8}$ Both claim to return followers to the origins of their religion, but the utopian solution tries to retrieve its liberating spirit in order to transform the given society, whereas the mythical solution proposes a return to legal code in order to restore divine order, or, additionally, to recapture the ancient community's revelatory experience. Utopian reactions tend to advocate more egalitarian social and, especially, gender relations, whereas mythical reactions tend to favor tradition, hierarchy, and patriarchal authority - what we call "fundamentalism." Within this concept we distinguish further between legalistic-literalist fundamentalism on the one hand, and charismatic fundamentalism on the other. The former centers exclusively on rigorous religious conduct, which is combined in the latter with ecstatic experience.

\section{Fundamentalisms and the Crises of Modernity}

The resurgence of religious movements on a global scale is an indicator of dramatic social transformations. Often, these movements are interpreted as reactions to and protest against modernity. We find such analyses too general, and propose instead to read the ideologies and actions of religious movements as an articulation of protest by definite groups of people against very specific features of modernity, most likely those experienced in negative terms. Thus, it is of significance that over the last decades a great number of religious movements in the United States and worldwide has articulated as their central concern problems of the family and gender relations, of sexual and social morality. Although one should not reduce the complexity of these movements to a single issue or ignore other agendas, it seems safe to state that family and gender relations have been the single most important topic recently addressed by religious movements. 
Many recent religious groups advocate strict, patriarchal structures of authority, morality, and gender relations. ${ }^{9}$ This is true not only for less industrialized countries, where patriarchal authority remains widely institutionalized, but also in such advanced capitalist countries as the United States, where even highly educated, middle-class women join neopatriarchal religious groups and support their antifeminist agendas. ${ }^{10}$ Our approach suggests that the protest and ideals articulated in neopatriarchal ideologies should be taken seriously as indicators destabilizing and threatening dimensions of life experienced by those who join such movements. One should not assume, however, that protest is based on homogeneous experiences of eroding family structures, or that neopatriarchal ideals refer to a homogeneous imagination of social order. Rather, the concrete meanings of both protest and ideals vary according to class, gender, age, or ethnicity, and "fundamentalism" may disguise more than it explains unless one delineates its unique and context-specific significance.

Many recent studies have contributed considerably to a more differentiated view of such religious movements as fundamentalism, evangelicalism, and Pentecostalism by pointing out the great diversity among all religious groups that advocate patriarchal gender relations and structures of authority. ${ }^{11}$ These studies, many of which focus on Protestant Christianity in North America and Latin America, emphasize the differences between more legalistic-literalist fundamentalists and charismatic, Pentecostal groups. For example, Margaret Lamberts Bendroth argues about North American Protestantism that, "although many holiness and Pentecostal groups may rightly assume the fundamentalist label, the two groups parted ways decisively in regard to the 'woman question.' For the purpose of my argument, I have chosen to differentiate the main body of fundamentalists from their charismatic conservative brethren. For although to outsiders they appeared nearly indistinguishable, fundamentalists abhorred the use of women preachers in holiness churches almost as vehemently as they opposed the practice of speaking in tongues." ${ }^{12}$ Others have supported this view and, in a similar fashion, Elizabeth E. Brusco emphasizes the difference between heavily charismatic and more conservative Colombian evangelicalism, especially in their effects on gender relations and ideology. ${ }^{13}$ This article builds on such insights by looking at the different conditions under which women in varied neopatriarchal religious movements address their specific concerns.

The literature suggests that for women in more charismatic groups patriarchalism plays a different role than for those in more legalisticliteralist ones. In charismatic groups, women more actively use patriarchal structures of authority to further their own interests, especially in the restructuring of the family and remoralization of men. In literalist-legalistic 
fundamentalist groups, patriarchalism serves rather as an authoritarian and oppressive instrument of male domination. Although we do not doubt the accuracy of the reports on North American and Latin American fundamentalism and Pentecostalism, we would like to further explore these differences and their causes, particularly the structural conditions under which the emancipatory potential of charismatic fundamentalism for women can be realized. What makes Pentecostalism apparently more open to the needs and interests of (lower-class) women? Can it be attributed to doctrine, charismatic style, or a homogeneous lower-class composition? Will it change over time into a more or even less rigid patriarchal structure? Is this picture of charismatic fundamentalism confirmed when we look outside of the American context?

In order to study these questions, we first systematize the structural characteristics of charismatic and legalistic-literalist fundamentalism, proposing an ideal-typical juxtaposition between the two fundamentalisms based on North American and Latin American case studies. ${ }^{14}$ By focusing on the distinctive structures of each system and their consequences on gender relations among charismatics and legalist-literalists, two central and related questions arise: First, what counts as "political" for adherents to the two traditions? Only the public space, or also the domestic space? Second, who has the authority to publicly sanction whom? Are only men entitled to publicly sanction female behavior, or can women also sanction male behavior in public? ${ }^{15}$ In a second step, we use this model for the analysis of comparable cases in South Korea where evidence suggests that charismatic fundamentalism does not necessarily lead to more gender equality.

\section{Legalistic-Literalist versus Charismatic Fundamentalism}

\section{Social Composition}

Both charismatic and legalistic-literalist fundamentalism associate on the principles of shared religious beliefs and visions of social moral order rather than shared class interests. Nevertheless, class composition impacts their organization and ideology. Previous theorists assumed that the social composition of all kinds of fundamentalist movements was predominantly lower class. But recently this view has been challenged and modified considerably. Nancy Ammerman has proven that contemporary legalisticliteralist types of Protestant fundamentalism can be solidly middle class. ${ }^{16}$ And Martin Riesebrodt has shown that this type of fundamentalism often attracts a mixed-class clientele which reflects the varied social composition of Protestantism in general. ${ }^{17}$ Only charismatic fundamentalism has shown a homogeneous lower-class profile. ${ }^{18}$ Tracing the emer- 
gence of American Pentecostalism from its Holiness background in the early 1900s, Robert M. Anderson found that adherents were predominantly lower class. Such religious movements often draw their strongest support from the agrarian, artisan, and small entrepreneurial classes most adversely affected by urban-industrial change. ${ }^{19}$

Women tend to be overrepresented in nearly all religious groups, but more so in charismatic fundamentalism than in legalistic-literalist groups. Cultural and class affinities based on education, income, and aspirations affect gender solidarity, and, in legalistic-literalist fundamentalism, the heterogeneous class composition divides women according to their educational background and agendas. Such differences have a major impact on the organization, ideology, gender relations, and political understanding of these movements.

\section{Leadership and Religious Qualification}

Fundamentalist movements are primarily lay movements, a fact often hidden because of the prominent position of preachers and, especially, religious legal experts-for example, in Iranian Shia fundamentalism. As expected, the social composition of a movement has a major impact on its leadership. Because legalistic-literalist fundamentalist movements tend to be socially heterogeneous they are led most often by well-educated middle-class men. First of all, religious qualification is measured, among other things, by knowledge of sacred texts, religiolegal knowledge, exegetical ability, and preaching, and middle-class men are most likely to have such skills. They tend to be better educated theologically, and better equipped to articulate an ideology that fuses different class segments into one group.

In legalistic-literalist fundamentalist groups, one finds a firmly institutionalized predominance of values which favor the middle class over those of the lower classes, as well as men over women. Even if they are numerically in the majority, the lower classes and women are generally in a subordinate position. In her study of a fundamentalist congregation in a middle-class, northeast American suburb in the late 1970s and early 1980s, Ammerman observes that women are completely marginalized from the church's leadership structure, despite their numerical predominance and comparable educational background to men. "To say that authority at Southside [Church] is in the hands of men of God is quite literally true. Women are so thoroughly outside the official power structure that an all-male committee can be described as a cross-section of the congregation." ${ }^{20}$ In this church, the biblical model for social institutions-authority and submission-is firmly established. This includes the deference of 
a congregation to the pastor in church, an employee to superiors at work, a citizen to officials in the government, and a woman to her husband at home. Similarly, Bendroth notes the consistent absence of female leadership in conservative Protestantism in America over the past fifty years. The orientations of evangelicalism have become overwhelmingly masculine, despite the fact that women have comprised two-thirds to three-fourths of the members of Protestant denominations. ${ }^{21}$

Compared to more abstract, complex, and sophisticated ideologies, which often are designed to appeal to people from different class backgrounds, charismatic fundamentalist ideology tends to be simpler and more direct, since it is supposed to appeal to people who share many experiences and problems. Leaders of socially homogeneous charismatic groups thus typically possess similar educational achievements as the other members. Furthermore, leaders' religious qualifications are not limited to religious knowledge and pious conduct, but include and emphasize charismatic experience. Whereas religious knowledge is often understood as men's domain, especially in legalistic-literalist groups, charismatic experience is theologically gender neutral and often the domain of women. Although men monopolize religious knowledge in charismatic groups, women have access to leadership positions through their charismatic calling.

The charismatic experience is central to Pentecostalism. Although Pentecostals engage in biblical exegesis, direct, personal contact with God through baptism of the Holy Spirit rather than intellectual understanding of the Bible, is the ultimate goal of their practices. "True understanding of Pentecostal doctrine always derives from intimate contact with God; rational analysis is always a weak and faulty tool when the analyst relies solely upon his own natural intellectual powers. ${ }^{22}$ Charismatic religions such as Pentecostalism historically have afforded women the most opportunities to occupy positions of leadership, and even prominence. ${ }^{23} \mathrm{Al}-$ though by no means in the majority, several female Pentecostal leaders, such as Aimee Semple McPherson, have risen to positions of national leadership and legendary renown based on their charismatic authority. Sharing humble rural-agrarian origins with male leaders and their constituents, these women typically defend their authoritative roles as special gifts from the Holy Spirit. While most stopped short of arguing for ordination, they clearly saw their calling as a sign of the spiritual outpouring that Old Testament prophets predicted for latter days. ${ }^{24}$

In contemporary Latin America as well, much of Protestantism's appeal to the lower classes is due to its more egalitarian, democratic orientation, especially in contrast to Catholicism. One of the ways in which Protestant churches distinguish themselves from Catholic churches is in 
their efforts to encourage women's fuller participation. In his study of a Brazilian charismatic congregation, Jorge E. Maldonado writes, "the empowerment of couples in the leadership of the church and the recognition of women as partners in the ministry have been of paramount importance in a country where Catholicism traditionally requires that only celibate men and celibate women reach the status of sanctity, piety, and ministry through life based in a religious community or a monastery." ${ }^{25}$

\section{Gender Ideology, Family, and the Religious Role of Women}

In legalistic-literalist fundamentalism, women tend to be seen as less qualified religiously than men and, at the same time, are prevented from achieving religious qualification by circular, misogynist gender ideology. Where men are seen as heroic, rational, moral, and responsible, women are believed to be intellectually and morally weak, sexually dangerous to men, and polluters of sacred spaces. They are forbidden to interpret sacred texts and preach, or speak in public. Ammerman, for example, shows that the fundamentalist church's exclusion of women from power is accompanied by strict and literal application of biblical injunctions against women speaking in the church, as described in I Corinthians 14:35. These proscriptions prevent women from playing a major role in decision making and teaching in any situation where their husbands might be students. Practically, this means that women cannot serve on committees and boards, or even teach adult Bible classes. ${ }^{26}$

Describing the roots of antifeminist fundamentalist ideology in America, Bendroth shows how in early dispensationalism the original sin of Eve was used as the ultimate justification for women's inferior position and character. ${ }^{27}$ With the belief that original sin could not be changed by human beings, these early views reflected the idea that the nature of Eve's sin revealed her original frailty and "moral disability," and confirmed the wisdom of her subjection, making feminine subordination inevitable. Dispensationalists also looked on women preachers and leaders, especially those in the Pentecostal traditions, with contempt, believing them to be a "demonic counterfeit" lacking in true knowledge and wisdom. ${ }^{28}$

On the contrary, fundamentalists portrayed men as rational guardians of doctrine, and fundamentalism was increasingly imbued with a masculine ideal especially in an attempt to defend and distinguish it from the "effeminate" faith of modern theology. Fundamentalism became associated with an assertive masculinity that thrived on controversy and was characterized by its hardheaded rationalism. Male leaders promoted "ornamental womanhood," which frowned upon any activities that took women from their appointed role in the home, and equated rational- 
ity with masculinity, of which women were incapable. Fundamentalism also affirmed nineteenth-century masculine ideals of boldness and mastery, linking them to revivalism's emphasis on victory and power. "'A single man filled with the Holy Spirit can of course do what a thousand cannot do without it. He is the strong man, the wise man, the effective man."'29

In charismatic fundamentalism, too, men and women's religious knowledge is qualified differently, but they have equal access to charismatic gifts. Although women may not always preach, they can speak in public when "moved by the spirit." Since the spirit enters women and speaks through them, women cannot as easily be characterized in misogynist terms as long as charismatic elements have not become institutionalized and controlled by men. In charismatic fundamentalism, man is not necessarily a hero, but rather a sinner, drunkard, gambler, or womanizer who has to be remoralized in order to become a responsible husband and father.

Brusco argues that one of the most important functions of Colombian evangelicalism rests in the revolutionary transformation of family-level gender relations through women's domestication of men. At the heart of women's attempts to reform men and reorient them toward their families is reformation of their machismo behavior, which includes drinking, womanizing, gambling, physical abuse, and individualistic (as opposed to familial) consumption patterns. ${ }^{30}$ Similarly, Lesley Gill writes: "Yet, even as the church subordinates women, Pentecostal doctrine also dictates rigid behavioral norms for men, and this serves to reform male behavior in accordance with some of the needs and desires of women. Married women and their children, for example, benefit from an improvement in the material circumstances of their households because male resources previously spent on alcohol, cigarettes, gambling, and extramarital liaisons are directed back into the domestic unit." ${ }^{31}$ Gill also finds Pentecostal services in Latin America to be more participatory. These churches often allow women, upon receiving the Holy Spirit, to preach. "Women in this setting are not merely passive recipients of a religious message. They actively participate in the experience by singing and directing hymns, receiving the Holy Spirit, testifying, and even preaching on rare occasions." ${ }^{32}$

Differences in gender ideology that are related to foundations of religious qualifications have an effect on women's ability to access public religious discourse. They also point to other major differences between charismatic and legalistic-literalist fundamentalists, namely their understandings of private and public, and their organization of space for resistance. 


\section{Public Discourse and the Political}

The public discourse of legalistic-literalist fundamentalism focuses comprehensively on moral decay. According to such discourse, corruption permeates society and the aim of religion is to restructure moral order through institutional and political means. Since women are often seen as the sources of this moral decay, male control of women and their bodies is prominent in public rhetoric. ${ }^{33}$ The domestic sphere and gender relations are subsumed under these regulations, but the emphasis is on men's control of women and their bodies. As a consequence of this misogynist view, women in legalistic-literalist fundamentalism have few religious weapons to resist male authority. Because women are regarded as irrational, immoral, and religiously less knowledgeable and thus are excluded from public religious discourse, their sources for resistance primarily come from outside the religious sphere. Men also control religious public space, making it unlikely that concrete domestic problems of gender relations, such as abusive male behavior, would be addressed there. Religious law and morality regulate the domestic sphere, but it is private and supervised by the male head of the household.

For women in charismatic fundamentalism, however, there seems to be more religious space and legitimacy for resistance. Since they are seen as "more spiritual" than men, women possess a certain degree of religious authority and can shame and sanction their husbands religiously, proving female moral superiority. ${ }^{34}$ Most important, women can address domestic problems in front of the congregation in the form of prophecy. John R. Burdick explains this "classical source of female power in pentecostalism" as follows: "Once a man converts, his wife enjoys unparalleled safeguards over his behavior. Crença rejects all the elements of the male prestige complex-drinking, smoking, gambling, fighting, and adultery-as the work of the Devil, and subjects men to discipline should they indulge in any of these practices. Yet direct sanctions rarely need to be applied, for cautionary tales are constantly circulating about sinners revealed by prophets in front of the whole congregation." 35

Since in charismatic fundamentalism the domestic sphere and gender relations can be addressed through public religious discourse, the domestic becomes both public and implicitly political. In line with the findings of Brusco and others, Maldonado finds that Venezuelan fundamentalism utilizes traditional patriarchal ideology of family relations as a means to deal with male absence from the family. By teaching men about family management, with an emphasis on discipline, seriousness, cooperation, demonstration of affection, compassion, and, above all, responsibility, patriarchal family ideology encourages male economic support and 
marital fidelity. He reports, "in a region where machismo has been part of the fabric of the culture, the headship ideology may be perceived as protection of women and children and the attempted easing of a heavy burden from the shoulders of proletariat and subproletariat women." 36

Women in legalistic-literalist fundamentalism have to use different strategies in order to carve out a public space for themselves. Since middleclass male criteria define religious qualification, women often use these same legalistic-literalist strategies to legitimize their inclusion in and admission to full membership, equal rights, or even leadership positions. By doing so, they affirm male definitions of religious qualification based on knowledge, rationality, and morality; they also confirm male understandings of the political and the divide between public and domestic. These movements thus give lower-class women far fewer opportunities to articulate their own specific interests than do charismatic movements.

\section{Ideal-Types and Their Uses}

Typologies are not designed to be used as boxes in which empirical cases have to fit. To the contrary, there are few cases that totally fit either the charismatic or the legalistic-literalist type as described here. Ideal-types as methodological tools are systematic exaggerations of features of social phenomena which are regarded as particularly significant for the characterization of differences. Although all cases fall somewhere in-between, this is the strength, not the weakness, of the typological method since no model can capture adequately the complexity of historical phenomena. Instead, we must look at each case individually and analyze how and to what extent it adheres to certain features of one type or another. We recognize, however, that this can always be a matter of approximation only.

We base all the features represented here as an ideal-type of charismatic fundamentalism on earlier, less institutionalized phases of such movements in North America and Latin America. As we know, however, the more this type of fundamentalism gets institutionalized and charismatic experiences become controlled, the more it emphasizes patriarchal authority. ${ }^{37}$ Even among lower-class Latin American Pentecostals, men dominate the power structure of the churches..$^{38}$ According to Melvin Williams, in charismatic black American churches where women have considerable de facto power, they still are considered "inferior to men." God may call women as well as men to deliver sermons, but there is a distinction between female missionaries' "teaching" and male ministers" "preaching"-only men may stand in the pulpit to preach. Women missionaries travel and deliver sermons in various churches, but can become well- 
known and prosperous only as long as they recognize their subservience to a male "head." 39

These features of charismatic fundamentalism offer useful clues to their appeal for men. Despite the space they provide for women to negotiate gender and status, the ultimate aim of charismatic religious congregations is to restore family and social stability by reinstating patriarchal structures of authority and morality. Remoralization of men can be attractive to them because in addition to allowing men to escape the often destructive pressures of machismo, it gives them a new honored status as a responsible head of the family. Male conversion is "double-edged": although it may present a victory for women, it also acknowledges the solidification of men's authority at home. ${ }^{40}$ As Salvatore Cucchiari observes in his study of Sicilian Pentecostalism, while Pentecostal conversion for women may represent a "struggle for gender liberation" and means of "empowerment" in the face of crisis in the hegemonic gender system, men "experience the church community as a haven of nonthreatened male honor and privilege, as a revitalization of the prevailing system of patriarchy."41

Most legalistic-literalist fundamentalist groups provide women to a certain extent, however, with opportunities to claim spaces in which to address their concerns. In addition to allowing women to create their own organizations and semiautonomous spaces, negotiations of gender relations stressing mutuality and partnership may occur, both in religious ideology and practice, as Susan D. Rose's and Judith Stacey's studies of contemporary evangelical women in the United States amply have demonstrated. ${ }^{42}$ Even in more traditional societies, fundamentalism can become a resource with which women can renegotiate the traditional "patriarchal bargain" to their advantage, by being able to hold men more strictly to their end of the deal. ${ }^{43}$ In other words, gender relations are not fixed but negotiated in both types of fundamentalism. But depending on the type, the opportunities and constraints as well as the strategies and outcomes will look different.

\section{Charismatic Fundamentalism in South Korea}

Since our ideal-types have been developed out of case studies of North American and Latin American Protestant fundamentalism, South Korean Protestantism provides a useful test case for their effects on gender politics under quite different conditions. ${ }^{44}$ As in Latin America, Protestantism in South Korea represents a relatively recent religious transmission from North America. First introduced in the late 1800s, Protestantism-of a mostly fundamentalist, evangelical variety-exploded in South Korea 
during the rapid industrialization phase of the 1970s and 1980s, and presently claims close to 25 percent of the nation's population. ${ }^{45}$ Developing under conditions of rapid social change similar to those in Latin America, Protestantism has served many analogous functions in South Korea, not the least of which has been its special importance to women attempting to cope with the challenges of a rapidly transforming environment. However, the study of Protestantism in South Korea also provides an opportunity to qualify findings regarding fundamentalism and gender relations in Latin America. For women in South Korea, charismatic fundamentalism does not represent a vehicle for negotiation toward greater gender equality within the church or the family, but, to the contrary, is a mechanism that affirms and reinforces existing structures of patriarchal authority and gender relations.

As in Latin America, churches in South Korea historically have been known for their strong charismatic character, influenced, as many see it, by the native shamanistic tradition centered on women. ${ }^{46}$ Although stronger charismatic and Pentecostal elements can traditionally be found in the lower-class congregations, ${ }^{47}$ one of the distinctive features of South Korean fundamentalism is that many of its churches, irrespective of their class composition or denominational affiliation, display charismatic tendencies. Jae Bum Lee has found, for example, that in South Korea, charismatic elements play a major role in some of its largest congregations, both Pentecostal and non-Pentecostal, many of which possess a predominantly urban, middle-class membership. ${ }^{48}$ In South Korea, however, these charismatic elements have not served as a source for a transformation of patriarchal structures of authority in these churches nor any notable changes in the basic position of women.

Most lower-class churches, independent of denominational affiliation, possess a strong charismatic orientation. Revealing strong Pentecostal influences, many of them focus on baptism of the Holy Spirit and healing practices. However, despite this strong charismatic nature and the numerical preponderance of women, ${ }^{49}$ a striking aspect of these churches is their distinctly patriarchal culture. Similar to middle-class churches, lower-class Korean churches are characterized by a rigorously patriarchal structure and ideology that articulates clear subordination of women both in the church and in the family.

One way in which patriarchal principles are expressed in Korean Christianity is a nearly complete exclusion of women from almost all forms of public authority and power within the church hierarchy. Unable to rise beyond the position of deaconess, women are usually limited to such woman-centered group activities as evangelism, home Bible study meetings, and other support-oriented tasks. In the home, the strict fundamen- 
talist ideology of the husband's headship and wife's obedience and submission is strictly applied and upheld.

Moreover, in spite of the centrality of the charismatic experiences in many South Korean churches, this charismatic culture rarely provides a means by which female interests are articulated or authority is exercised. In general, these charismatic experiences are limited to serving as vehicles for women's prayer and emotional and spiritual release. They rarely serve as mechanisms for public sanction of male behavior or assertion of female interests. In other words, one finds, even in lower-class, Pentecostal-type South Korean churches, pervasive and stringent institutionalization of patriarchal principles without the counterbalancing emphases on female charismatic and moral authority that are more obvious in some Latin American cases.

Many scholars have noted that a major source of Korean Protestantism's patriarchal ideologies is Confucianism, whose principles all too easily have been adapted, along with shamanism, to fundamentalist Christianity. ${ }^{50}$ The charismatic, utilitarian, and this-worldly tendencies characterizing Korean Protestantism reflect the spirit of traditional shamanism, while the hierarchical, patriarchal, and authoritarian character of Korean Protestantism is, in part, an indigenization of Confucian elements. ${ }^{51}$ In terms of gender relations, the traditional Confucian worldview, which asserts female inferiority while privileging motherhood, is fused with contemporary fundamentalist views on gender. This results in a powerful ideology which legitimates strict subordination of women while glorifying her role as guardian of the family.

The ideologies and organizational structure of patriarchy are more firmly institutionalized in middle-class South Korean churches, and resemble the North American model of traditional fundamentalist churches..$^{52}$ Indeed, in South Korean churches, reinforcement of existing patriarchal ideals and structures is accomplished more systematically and explicitly than in North America. For example, similar to family education programs of American fundamentalist churches, many larger middle-class churches in South Korea boast as the centerpieces of their educational programs various types of family seminars designed to inculcate and reinforce traditional patriarchal family values. The values and the model of family advocated in these seminars go beyond the ideal nuclear "Christian" family of the West. They are based rather on the traditional Confucian Korean family ideal which, though transmuted into a nuclear family form, strictly upholds patrilineal-patrilocal principles and the obligations and subordination they imply for women. The audience for these seminars is mostly women.

Moreover, compared to their lower-class counterparts, the charismatic 
elements in middle-class churches are even more strictly contained. Although women are allowed to display their charismatic experiences during the religious service, these expressions are controlled and regulated implicitly by the tight structure of the worship service, and women's equality of access to charismatic qualifications does not translate into more general access to power or more egalitarian gender ideology. In fact, little difference exists in South Korea between charismatic, middle-class congregations and traditionally fundamentalist, middle-class congregations in terms of women's relationships to men. Both reflect and embody the patriarchal structure, ideals, and ethos of the larger society.

Contrary to Latin American experiences, female participation in Korean lower-class churches is less focused on curbing machismo (in the sense of patriarchalism grown anomic ${ }^{53}$ ) than it is a means by which women attempt to cope with the effects of an extremely patriarchal family structure. Although their difficulties also include male abandonment and abuse, Korean women's central problems most often stem from the oppressive restrictions and injustices of Confucian family structure, particularly the mistreatment and harsh demands of in-laws and husbands.

In many cases, the severity of these problems results in the particular crisis of the modern Korean family form in contemporary South Korea. At the core of this crisis are contradictions arising from the preservation of certain features of traditional family organization despite transformation to a modern nuclear family and changed socioeconomic and cultural conditions. Although women have high educational levels and modern egalitarian ideas regarding family, gender, and conjugal relations have spread widely in South Korean society, the patriarchal structure and moral order of the Korean family have remained remarkably intact. For many women, the contradiction between their changed expectations and continued subordination and inferior treatment under the patriarchal family system has generated an intensified sense of frustration and oppression. For some, the severity of their problems has resulted in a variety of psychosomatic illnesses. ${ }^{54}$

One major reason for South Korean women's participation in evangelicalism is thus an attempt to obtain relief from these stresses through participation in the practices of a religious community, thereby expanding social networks with others in similar positions and striving for other-worldly salvation. This is even more so for middle-class women, who are more highly educated, and for whom the issue of machismo is even less relevant. Ironically, however, the guidance churches provide for these women leads to reinforcement of the very patriarchal system that lies at the heart of their problems. Upholding family order and harmony as their primary goal, churches' solutions strengthen the principle and 
practice of female submission to patriarchal authority, illustrating the extent to which evangelical Protestantism in South Korea serves as a vehicle for legitimation and preservation of middle-class, patriarchal gender order. ${ }^{55}$

Given the intensely conservative nature of Korean evangelicalism, why do Korean women so enthusiastically participate in evangelicalism? An important part of explaining this question is to answer why Korean women choose to accommodate or consent to religious patriarchy. Although a full exploration of the answers to these questions is outside the scope of this article, addressing the issues requires a culturally sensitive exploration of South Korean women's options, interests, and choices as shaped by the particular nature of the crisis of gender order in South Korean society; their position in the current economic and domestic structure; and their gender identities and subjectivities. For instance, it is possible that for many highly educated, modernized women in South Korea, the demands of the traditional family system are becoming increasingly illegitimate and intolerable in the modern context. However, lacking alternatives in a society that offers few economic opportunities for women or other viable forms of self-identity, many South Korean women may find that their best option lies in religious reinterpretation of the patriarchal family. ${ }^{56}$

This is not to suggest, however, that South Korean women of all classes do not employ various strategies of resistance or self-empowerment through religion. It is also not meant to suggest that women have no moral or spiritual authority or autonomous space within the church and at home. To the extent that all religions, fundamentalist or not, possess a contestatory potential, South Korean evangelicalism provides some means for women to negotiate relations of gender. It offers women a means to religiously transcend and acquire meaning for their sufferings, gain a certain degree of autonomy from men through their relationship with a higher power, and even regulate the conduct of their husbands. As in Latin America, a successful persuasion of husbands to convert can foster a change in their behavior-less drinking and gambling, more attention to wife and children-which improves family relationships. ${ }^{57}$ However, it appears that in South Korea, greater family harmony and improvements in the domestic situation are traded for further entrenchment of women's subordination, submission, and sacrifice to men under the patriarchal system.

\section{Conclusion: Reaffirmation versus Renegotiation of Gender Relations}

The North American and Latin American cases suggest that there can be major differences in the construction of gender relations and articula- 
tion of women's agendas as well as in the character of their political involvement between charismatic and legalistic-literalist types of fundamentalism. At the same time, South Korean materials show that these different outcomes are dependent less on the type of fundamentalism than on preexisting structures of authority. Our comparison suggests several hypotheses. When patriarchal structures of authority more or less are still functioning, then differences between charismatic and legalistic-literalist fundamentalism become minimized and patriarchal features become predominant, even in charismatic fundamentalism. In these cases, different degrees of politicization and understandings of the political are possible, but they all tend to affirm, stabilize, and reinvigorate the existing patriarchal ideology and order in the family and other institutional contexts. However, when the structure of authority in the patriarchal family breaks down and gender relations have to be renegotiated, charismatic fundamentalism offers women greater space than legalistic-literalist fundamentalism, although renegotiations also go on within the latter. In this case, a politicization (in the sense of Keddie's "new religious politics") is less likely to happen; it is more probable that the focus stays on renegotiations of gender relations within the patriarchal family model.

From our analysis, we conclude that it is insufficient to look at the impact of religion on gender relations and their politicization in isolation from the structures of authority in the family, and the political and economic orders. We do not deny that religion plays an important role in shaping and redefining gender relations. Our comparison, however, suggests that existing structures of authority widely constrain the extent to which religious repertoires have transformative effects of their own. But, religion certainly has an enormous impact on the cultural forms patriarchal family and gender relations may take. Whether or not the model offered here is valid beyond the cases considered remains to be seen. However, it may be a useful step for further explorations into the dynamics of religion and patriarchal gender politics.

\section{NOTES}

${ }^{1}$ Especially prominent are the respective volumes of the Fundamentalism Project edited by Martin E. Marty and R. Scott Appleby, Fundamentalisms Observed, Fundamentalisms and Society, Fundamentalisms and the State, Accounting for Fundamentalisms, and Fundamentalisms Comprehended (Chicago: University of Chicago Press, 1991-1995).

${ }^{2}$ See especially José Casanova, Public Religions in the Modern World (Chicago: University of Chicago Press, 1994).

${ }^{3}$ Nikki R. Keddie, "The New Religious Politics and Women Worldwide: A Comparative Study," article in this issue. 
${ }^{4}$ See Karen Offen, "Defining Feminism: A Comparative Historical Approach," Signs 14, no. 1 (1988): 119-57; and Martin Riesebrodt, "Fundamentalism and the Political Mobilization of Women," in The Political Dimensions of Religion, ed. Said Arjomand (Albany: SUNY Press, 1993).

${ }^{5}$ See especially Elizabeth E. Brusco, The Reformation of Machismo: Evangelical Conversion and Gender in Colombia (Austin: University of Texas Press, 1995); and John R. Burdick, Looking for God in Brazil (Berkeley: University of California Press, 1993).

${ }^{6}$ Martin Riesebrodt, "Theorizing Religion Globally," in Global Religion: A Handbook, ed. Mark Juergensmeyer (Oxford: Oxford University Press, 1999).

${ }^{7}$ Melford E. Spiro, "Religion: Problems of Definition and Explanation," in Melford E. Spiro, Culture and Human Nature (New Brunswick, N.J.: Transaction Books, 1994), 187-222.

${ }^{8}$ Martin Riesebrodt, Pious Passion: The Emergence of Modern Fundamentalism in the United States and Iran (Berkeley: University of California Press, 1993), 15-20.

${ }^{9}$ Helen Hardacre, "The New Religions, Family, and Society in Japan," in Fundamentalisms and Society, 294-310; and Riesebrodt, Pious Passion.

${ }^{10}$ Lynn Davidman, Tradition in a Rootless World: Women Turn to Orthodox Judaism (Berkeley: University of California Press, 1991); Debra Kaufman, "Patriarchal Women: A Case Study of Newly Orthodox Jewish Women," Symbolic Interaction 12, no. 2 (1989): 299-314, Debra Kaufman, Rachel's Daughters: Newly Orthodox Jewish Women (New Brunswick, N.J.: Rutgers University Press, 1991); and Judith Stacey, Brave New Families (New York: Basic Books, 1991). Patriarchalism is a very general term for a status system based on piety and honor where male gender and mature age are privileged over female gender and young age. Within this basic structure there are innumerable concrete forms of lived gender relations which range from partnership based on a gendered division of labor to authoritarian dominance of men over women. For a study of a variety of patriarchal forms in Islam, see Deniz Kandiyoti, "Islam and Patriarchy: A Comparative Perspective," in Women in Middle Eastern History, ed. Nikki R. Keddie and Beth Baron (New Haven, Conn.: Yale University Press, 1991).

${ }^{11}$ Margaret Lamberts Bendroth, Fundamentalism and Gender, 1875 to the Present (New Haven, Conn.: Yale University Press, 1993); Elizabeth E. Brusco, "The Household Basis of Evangelical Religion and the Reformation of Machismo in Colombia" (Ph.D. diss., City University of New York, 1986); Brusco, The Reformation of Machismo; Burdick, Looking for God; Salvatore Cucchiari, "Between Shame and Sactification: Patriarchy and Its Transformation in Sicilian Pentecostalism" American Ethnologist 17, no. 4 (1990): 687-707; and Lesley Gill, "'Like a Veil to Cover Them': Women and the Pentecostal Movement in La Paz," American Ethnologist 17, no. 4 (1990): 708-21.

${ }^{12}$ Bendroth, Fundamentalism and Gender, 4.

${ }^{13}$ Brusco, "The Household Basis"; Brusco, The Reformation of Machismo; Rosemary Skinner Keller, "Women and Religion," Encyclopedia of the American Re- 
ligious Experience: Studies of Traditions and Movements, ed. Charles H. Lippy and Peter Williams (New York: Charles Scribner's Sons, 1988), 1547-62; George Marsden, Fundamentalism and American Culture (New York: Oxford University Press, 1980); Riesebrodt, Pious Passion; and Grant Wacker, "Pentecostalism," Encyclopedia of the American Religious Experience, 933-45.

${ }^{14}$ See Riesebrodt, Pious Passion, 15-20, 39-46.

${ }^{15}$ Barbara Epstein, The Politics of Domesticity: Women, Evangelism, and Temperance in Nineteenth-Century America (Middletown, Conn.: Wesleyan University Press, 1981).

${ }^{16}$ Nancy Ammerman, Bible Believers: Fundamentalists in the Modern World (New Brunswick, N.J: Rutgers University Press, 1987).

${ }^{17}$ Riesebrodt, Pious Passion.

${ }^{18}$ Robert M. Anderson, Vision of the Disinherited: The Making of American Pentecostalism (New York: Oxford University Press, 1979).

${ }^{19}$ Anderson, Vision of the Disinherited, 224.

${ }^{20}$ Ammerman, Bible Believers, 56.

${ }^{21}$ Margaret Lamberts Bendroth, "The Search for 'Women's Role' in American Evangelicalism, 1830-1980," in Evangelicalism and Modern America, ed. George Marsden (Grand Rapids, Mich.: W. B. Eerdmans, 1984), 123, 127.

${ }^{22}$ Gary Schwartz, Sect Ideology and Social Status (Chicago: University of Chicago Press, 1970), 151.

${ }^{23}$ Anderson, Vision of the Disinherited.

${ }^{24}$ Bendroth, Fundamentalism and Gender, 44.

${ }^{25}$ Jorge E. Maldonado, "Building Fundamentalism from the Family in Latin America," Fundamentalisms and Society, 225.

${ }^{26}$ Ammerman, Bible Believers, 125.

27 "Dispensationalism" refers to a Protestant theological view which divides history into several dispensations. Each age is characterized by a different relationship between God and humans.

${ }^{28}$ Bendroth, Fundamentalism and Gender, 45-46.

${ }^{29}$ A. J. Gordon, quoted in Bendroth, Fundamentalism and Gender, 22.

${ }^{30}$ Brusco, Reformation of Machismo.

${ }^{31}$ Gill, "'Like a Veil,"” 717.

${ }^{32}$ Ibid., 713. 
${ }^{33}$ Riesebrodt, Pious Passion, 64, and Riesebrodt, "Fundamentalism and the Political Mobilization of Women," 248-51.

${ }^{34}$ Burdick, Looking for God, 111.

${ }^{35}$ Ibid., 114.

${ }^{36}$ Maldonado, "Building Fundamentalism," 230.

${ }^{37}$ Keller, "Women and Religion."

${ }^{38}$ Burdick, Looking for God.

${ }^{39}$ Melvin Williams, Community in a Black Pentecostal Church (New York: Harper \& Row, 1974), 31.

${ }^{40}$ Burdick, Looking for God, 114.

${ }^{41}$ Cucchiari, "Between Shame and Sanctification," 700.

${ }^{42}$ Susan D. Rose, "Women Warriors: The Negotiation of Gender in a Charismatic Community," Sociological Analysis 48, no. 3 (1987): 245-58; and Stacey, Brave New Families.

${ }^{43}$ Kandiyoti, "Islam and Patriarchy," 23-42.

${ }^{44} \mathrm{Much}$ of the information in this section is based on ethnographic fieldwork conducted by Kelly H. Chong between 1996 and 1997 in Seoul, South Korea.

${ }^{45}$ Won Moo Hurh and Kwang Chung Kim, Korean Immigrants in America (Madison, N.J.: Fairleigh Dickinson University Press, 1984).

${ }^{46}$ David Martin, Tongues of Fire: The Explosion of Protestantism in Latin America (Oxford: Blackwell Publishers, 1990); Sung Ja Park, "A Feminist Theological Study of the Faith Patterns of Korean Church Women: Emphasis on the Religious Psychopathological Phenomenon" (Ph.D. diss., Ewha Woman's University, Seoul, South Korea, 1993 [in Korean]); and Kwang-Sun Suh, "American Missionaries and a Hundred Years of Korean Protestantism," International Review of Mission 74, no. 293 (1985): 5-17.

${ }^{47}$ Here, "lower-class" indicates the lower middle class, working class, and the poor.

${ }^{48}$ Jae Bum Lee, "Pentecostal Type Distinctives and Korean Protestant Church Growth" (Ph.D. diss., Fuller Theological Seminary, 1986).

${ }^{49}$ By most accounts, women comprise over 70 percent of Protestant church membership in South Korea. Hyo-Jae Yi, "Christian Mission and the Liberation of Korean Women," International Review of Mission 74, no. 293 (1985): 93-102.

${ }^{50}$ Martin, Tongues of Fire; and Yi, "Christian Mission."

${ }^{51}$ Martin (Tongues of Fire) notes that the indigenization of Korean Protestantism, which incorporates Confucian elements, is startlingly similar to patronal 
relationships reproduced inside Brazilian Presbyterianism, which evolved from patterns on the hacienda (plantation).

${ }^{52}$ Ammerman, Bible Believers.

${ }^{53}$ Riesebrodt, Pious Passion, 254.

${ }^{54}$ Park, "A Feminist Theological Study."

${ }^{55}$ Yi, "Christian Mission," 101.

${ }^{56}$ Clifford Geertz once remarked that religion does not tell us "how to avoid suffering but how to suffer." See Clifford Geertz, "Religion as a Cultural System," in Anthropological Approaches to the Study of Religion, ed. Michael Banton (London: Tavistock Publications, 1966), 19.

${ }^{57}$ However, it is interesting to note that in South Korea remoralization of men often has adverse economic consequences. Since in South Korea, drinking and entertaining are an important part of running a business, a strict Christian lifestyle-avoiding cheating, drinking, and smoking - may actually impede business success and contribute to a family's economic decline. As a result, South Korean women have an ambivalent attitude toward husbands' remoralization. 